\title{
Integral Management of Irrigation Water in Intensive Horticultural Systems of Almería
}

\author{
Pedro Garcia-Caparros ${ }^{1}$, Juana Isabel Contreras ${ }^{2}$, Rafael Baeza ${ }^{2}$, Maria Luz Segura ${ }^{2}$ and \\ Maria Teresa Lao ${ }^{1, *}$ \\ 1 Agronomy Department of Superior School Engineering, University of Almería, Agrifood Campus of \\ International Excellence ceiA3. Ctra. Sacramento s/n, La Cañada de San Urbano, 04120 Almería, Spain; \\ pedrogar123@hotmail.com \\ 2 Institute of Research and Training in Agriculture and Fishery (IFAPA), Junta of Andalucia, La Mojonera, \\ Almería 04630, Spain; juanai.contreras@juntadeandalucia.es (J.I.C.); rafaelj.baeza@juntadeandalucia.es (R.B.); \\ marial.segura@juntadeandalucia.es (M.L.S.) \\ * Correspondence: mtlao@ual.es; Tel.: +34-950-015-876; Fax: +34-950-015-939
}

Received: 30 October 2017; Accepted: 1 December 2017; Published: 7 December 2017

\begin{abstract}
The development of intensive horticulture in Almería, with a huge increase in greenhouse surface area, is related to three essential factors: climatic characteristics, groundwater use and mulching sandy soil. The purpose of the present paper is to draw a picture of the integral management of water irrigation in the intensive horticultural systems in the region, by identifying the most significant water resource contributions and alternative water resources. Results indicate that the use of groundwater for the irrigation of horticultural crops in the greenhouses presents a high degree of overexploitation of the aquifers, but due to the continuous search for alternative water resources, such as desalinated and reclaimed water, as well as in-depth knowledge of the integral management of water irrigation through automated fertigation and localized irrigation systems, the current status of the water resources could be sustainable. Moreover, being conscious of the pollution generated by agricultural leachates, the horticultural system of Almería is implementing complementary sustainable systems such as recirculation, cascade cropping systems and phytodepuration for the reuse of the leachate. Considering all these factors, it can be concluded that the intensive horticultural system is on the right path towards respecting the environment and being sustainable in terms of water use.
\end{abstract}

Keywords: cascade cropping system; desalinated water; phytodepuration; recirculation; reclaimed water; sustainability; water resources

\section{Introduction}

Human activity and natural factors are depleting available water resources around the world. It is estimated that 21 of the 37 largest aquifers are seriously overexploited, since water consumption is increasing by $1 \%$ per year. Consequently, the Organisation for Economic Cooperation and Development (OECD) expects an increase in tensions in the availability of fresh water in 2050.

Almería is a province located in the south-east of Spain $\left(36^{\circ} 50^{\prime} \mathrm{N} 02^{\circ} 23^{\prime} \mathrm{O}\right)$ which supplies vegetables to Europe throughout the winter season due to intensive greenhouse horticulture production. Currently, the greenhouse area is 31,034 ha, of which 26,590 ha are under biological production [1]. The development of intensive horticulture in this region, with a huge increase in the greenhouse area in the last 50 years (Figure 1) is related to three factors: climatic characteristics, groundwater use and the use of mulching in sandy soils [2]. In addition, the continuous incorporation of new technological innovations has resulted in an improvement in the efficiency of this production system, achieving high profit yields in an environmentally sustainable framework. 


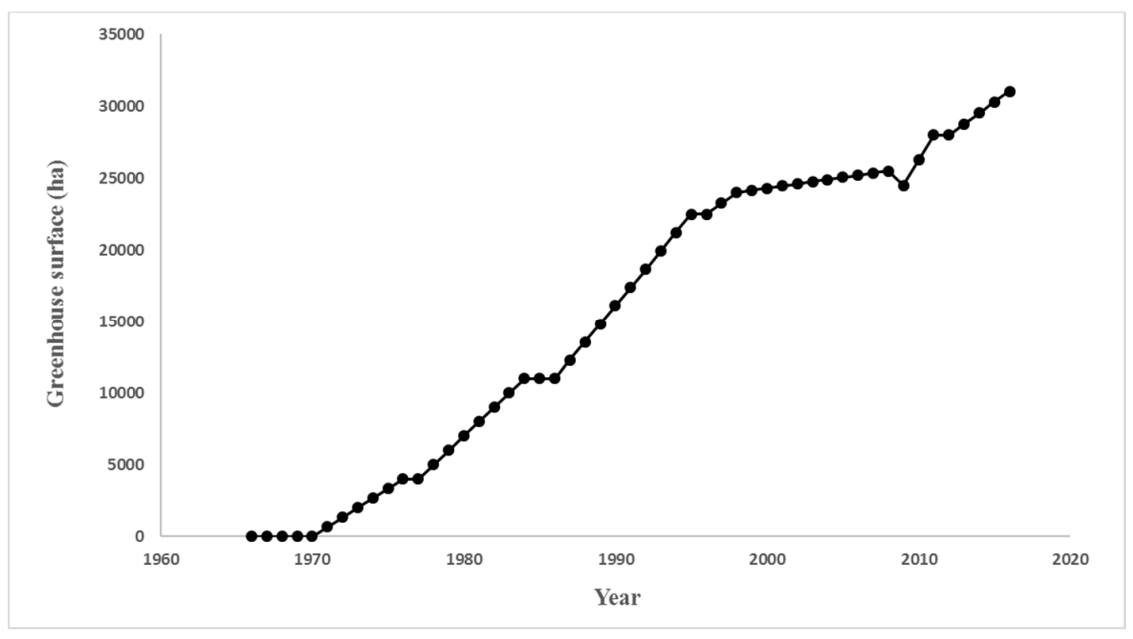

Figure 1. Evolution of the greenhouse surface expressed in ha in Almería (1966-2016) [3].

The greenhouse area is mainly concentrated in Campo de Dalias with 21,285 ha, Campo de Nijar and Bajo Andarax with 8468 ha and Bajo Almanzora with only 703 ha [1]. Currently, the greenhouses yield 3,027,000 tonnes of produce, $75 \%$ of which is destined for export [4].

According to the Köppen classification, the climate in the province of Almería is a BSk (tropical and subtropical steppe climate), with an annual average temperature of $19{ }^{\circ} \mathrm{C}\left(12{ }^{\circ} \mathrm{C}\right.$ and $22{ }^{\circ} \mathrm{C}$ during winter and summer, respectively). There are $2965 \mathrm{~h}$ of sun per year; the average relative humidity is around $70 \%$ and annual rainfall ranges from 200 to $250 \mathrm{~L} \mathrm{~m}^{-2}$ [5].

These climatic characteristics enable the development of horticultural greenhouse production in the region without the need for heating systems. Nevertheless, in the continuous search for an efficient production system with high profitability, it is necessary to point out that the establishment of greenhouse structures is also essential to the understanding of the huge development in horticultural production in this area. The most common greenhouse structure adopted in this region to satisfy the climatic requirements of vegetables associated with a winter commercial calendar of production is the parral-type greenhouse. This greenhouse is characterized by a low-cost structure composed of a vertical structure of rigid pillars (wood or steel) on which a double grid of wire is placed to attach the polyethylene plastic film [6].

The species traditionally grown in this region are tomato (Solanum lycopersicum), pepper (Capsicum annuum), cucumber (Cucumis sativus), melon (Cucumis melo), watermelon (Citrullus lanatus), green bean (Phaseolus vulgaris), eggplant (Solanum melongena) and zucchini (Cucurbita pepo). These species are adapted to average temperatures ranging from 17 to $28^{\circ} \mathrm{C}$, with limits of $12{ }^{\circ} \mathrm{C}$ (minimum) and $32{ }^{\circ} \mathrm{C}$ (maximum). Other desirable conditions for the adequate growth of these species are a relative humidity from 70 to $90 \%$ and a soil temperature higher than $14{ }^{\circ} \mathrm{C}$, since these species are sensitive to low temperatures and may suffer irreversible frost damage. The minimum daily radiation requirements of these species are estimated to be $8.5 \mathrm{MJ} \mathrm{m}^{-2}$ day $^{-1}$ (equivalent to $2.34 \mathrm{kWh} \mathrm{m}^{-2} \mathrm{day}^{-1}$ ) [7].

Table 1 shows the data of water consumption (expressed in $\mathrm{m}^{3} \mathrm{ha}^{-1}$ ) per crop in soil and hydroponics systems under greenhouse conditions of the main horticultural crops in the area [8], where water consumption per surface of each horticultural crop varies according to the growing system. More than $95 \%$ of this area corresponds to crops grown in a soil substrate [9].

Nowadays, one of the major problems in the horticultural production system in this region is the discharge of leachates into natural ecosystems generating the eutrophication of inland and coastal aquatic systems, as well as nutrient enrichment of terrestrial ecosystems [10]. In addition, there is increasing environmental concern amongst the population concerning the pollution of rivers and water in Europe, therefore the European Environment Agency (EEA) has established the Total Maximum Daily Loads for pollutants, considering $\mathrm{NO}_{3}{ }^{-}$as the greatest pollutant. 
Table 1. Water consumption per crop in soil and hydroponics systems under greenhouse conditions of the main horticultural crops grown in Almería [8].

\begin{tabular}{ccc}
\hline \multirow{2}{*}{ Horticultural Crop } & \multicolumn{2}{c}{ Water Consumption $\left.\mathbf{( m}^{\mathbf{3}} \mathbf{h a}^{\mathbf{- 1}}\right)$} \\
\cline { 2 - 3 } & Soil Culture & Hydroponics Culture \\
\hline Pepper & 3950 & 3933 \\
Tomato & 4110 & 6052 \\
Cucumber & 2780 & 2664 \\
Zucchini & 3490 & 3876 \\
Eggplant & 4190 & 4059 \\
Green bean & 1680 & 1554 \\
Watermelon & 2120 & 2262 \\
Melon & 2520 & 2360 \\
\hline
\end{tabular}

As far as agriculture is concerned, there is specific legislation concerning the environmental pollution generated. Directive 91/676/EEC aims to protect water quality in Europe by preventing nitrates from agricultural sources polluting ground and surface waters, and Directive (98/83/EC) establishes the criteria of the composition of the water considered suitable for human consumption. Both directives have established maximums of $\mathrm{NO}_{3}{ }^{-}$and $\mathrm{NO}_{2}{ }^{-}$(50 and $0.5 \mathrm{mg} \mathrm{L}^{-1}$, respectively) in water for human consumption in Europe.

The rapid development of greenhouse horticulture in Almería has coincided with a dramatic increase in the $\mathrm{NO}_{3}{ }^{-}$pollution of aquifers. The region is now classified as a Nitrate Vulnerable Zone in accordance with the European Union Directive.

Under such a problematic situation, there is a lot of research focused on the development and implementation of management practices to reduce nitrate leaching losses. For instance, Gallardo et al. [11] and Granados et al. [12] reported that there was a reduction in nitrate discharges to the environment through the management of leaching fraction and nitrogen supplies in horticultural crops.

The main aim of this work is to show the current status of water resources in the horticultural production system in Almería, considering the use of alternative water resources as well as the implementation of new technologies focused on the improvement of water use efficiency, and the reuse and/or treatment of leachates in order to improve the sustainability of this system. Moreover, this work could be very useful, worldwide, in horticultural production areas with a water scarcity problem similar to the one in Almería.

\section{Current Status of Conventional Water Resources}

According to the National Hydrological Plan 2015 (CMAOT) [13], the horticultural production system in Almería uses water from five river basins: the Adra river basin and the Dalias aquifer (III.4), the Andarax river basin (IV.1), the Campo de Nijar basin (IV.2), the Carboneras and Aguas river basin (V.1), and the Almanzora river basin (V.2) (Figure 2).

Table 2 shows some hydrological characteristics of the river basins, the irrigation consumption and the horticultural water exploitation index (annual total abstraction of fresh water for horticultural production divided by the long-term average fresh-water resources) [13]. The largest river basin is III.4 (the Adra river basin and the Dalias aquifer) which has a surface of $1457 \mathrm{~km}^{2}$ with surface water supplies of $49.3 \times 10^{6} \mathrm{~m}^{3}$, groundwater availability of $97.8 \times 10^{6} \mathrm{~m}^{3}$ and an irrigation consumption of $168.3 \times 10^{6} \mathrm{~m}^{3}$ per year. The smallest river basin is IV.2 (the Campo de Nijar basin) which has a surface of $780 \mathrm{~km}^{2}$, with surface water supplies of $0.4 \times 10^{6} \mathrm{~m}^{3}$, groundwater availability of $11.2 \times 10^{6} \mathrm{~m}^{3}$ and an irrigation consumption of $34.3 \times 10^{6} \mathrm{~m}^{3}$ per year. In all these systems, the main source of water is groundwater. Moreover, the table shows the horticultural water exploitation index data in each river basin. River basin IV.1 is the only one with a value of water exploitation index lower than 1 considering only the irrigation consumption, which means that the rest of the systems are overexploited. This status 
of overexploitation has been endured due to the high volume of groundwater in the aquifers. In these river basins, there are problems of seawater intrusion, a fall in the water table levels (which results in an increase in the electrical conductivity of water), and recourse to pumping in order to obtain the water needed. Although irrigation is the activity with the greatest water demands (83.6\%), there are other activities which demand a great volume of water, such as urban requirements $(14.7 \%)$ (Table 3). The status of the river basins agrees with Downward and Taylor's [14] data, which reported that the water supply capacity in the region of Almería was not sustainable for the horticultural production system.

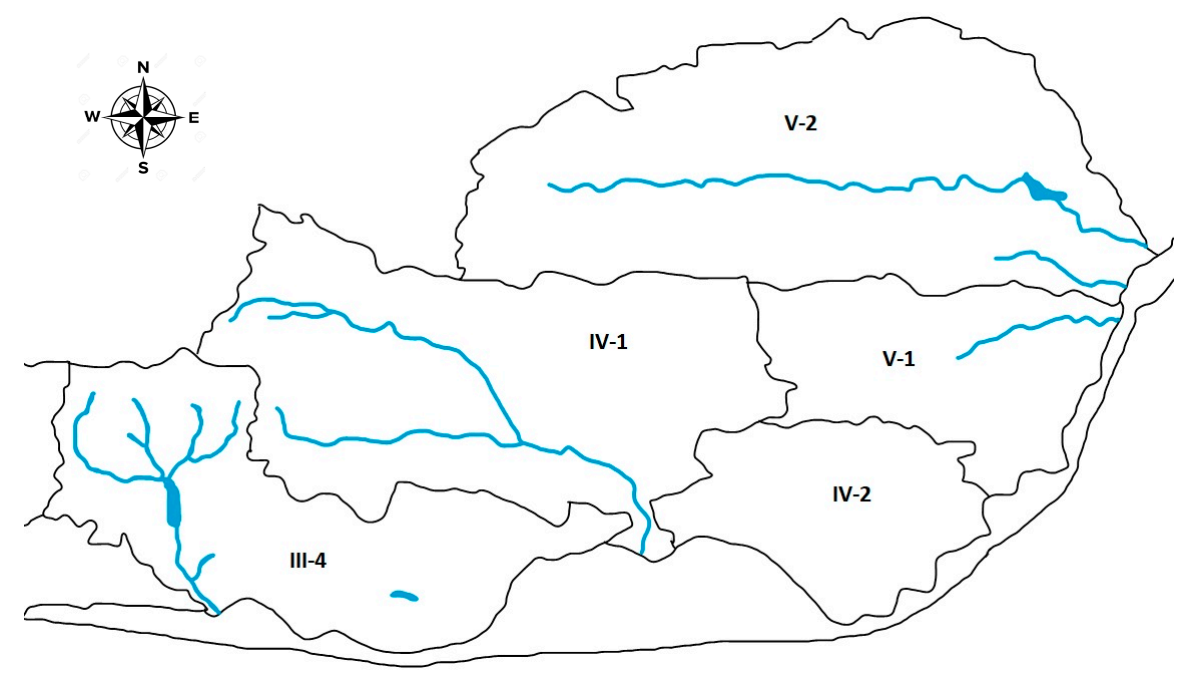

Figure 2. Scheme of the distribution of water resources in Almería (own resources). Scale 1:1,000,000. III.4: the Adra river basin and the Dalias aquifer, IV.1: the Andarax river basin, IV.2: the Campo de Nijar basin, V.1: the Carboneras and Aguas river basin and V.2: the Almanzora river basin.

Table 2. Surface, surface water supplies, groundwater available, total water available, irrigation consumption and horticultural water exploitation index in the river basins of Almería [13].

\begin{tabular}{|c|c|c|c|c|c|c|}
\hline Systems & $\begin{array}{c}\text { Surface } \\
\left(\mathrm{km}^{2}\right)\end{array}$ & $\begin{array}{c}\text { Surface Water } \\
\text { Supplies }\left(10^{6} \mathrm{~m}^{3}\right)\end{array}$ & $\begin{array}{l}\text { Groundwater } \\
\left(10^{6} \mathrm{~m}^{3}\right)\end{array}$ & $\begin{array}{l}\text { Total Water } \\
\left(10^{6} \mathrm{~m}^{3}\right)\end{array}$ & $\begin{array}{l}\text { Irrigation Consumption } \\
\left(10^{6} \mathrm{~m}^{3} \text { year }^{-1}\right)\end{array}$ & $\begin{array}{c}\text { Horticultural Water } \\
\text { Exploitation Index }\end{array}$ \\
\hline III.4 & 1457 & 49.3 & 97.8 & 147.1 & 168.3 & 1.1 \\
\hline IV.1 & 2161 & 18.6 & 26.4 & 45.0 & 44.1 & 0.9 \\
\hline IV.2 & 780 & 0.4 & 11.2 & 11.6 & 34.3 & 2.9 \\
\hline V.1 & 925 & 1.1 & 9.0 & 10.1 & 21.3 & 2.1 \\
\hline V.2 & 2500 & 16.0 & 29.1 & 45.1 & 85.9 & 1.9 \\
\hline Total & 7823 & 85.4 & 173.5 & 258.9 & 353.9 & 1.4 \\
\hline
\end{tabular}

Table 3. Water consumption expressed in a percentage itemized by activities in each river basin [13].

\begin{tabular}{cccccc}
\hline \multirow{2}{*}{ Systems } & \multicolumn{5}{c}{ Water Consumption } \\
\cline { 2 - 6 } & Urban & Irrigation & Animal Husbandry & Golf Courses & Industry \\
\hline III.4 & 20.0 & 79.2 & 0.0 & 0.7 & 0.0 \\
IV.1 & 8.9 & 88.4 & 0.2 & 0.0 & 2.5 \\
IV.2 & 4.8 & 93.9 & 0.2 & 1.0 & 0.1 \\
V.1 & 27.0 & 68.2 & 0.2 & 4.1 & 0.5 \\
V.2 & 9.0 & 88.6 & 0.8 & 0.7 & 0.9 \\
Total & 14.7 & 83.6 & 0.3 & 0.9 & 0.6 \\
\hline
\end{tabular}

With respect to the lithology of these aquifers, the Spanish Institute of Geology and Mining (IGME) [15] describes the aquifers of Almería as follows. Aquifer III.4 is composed of two layers: a shallow layer with gravel and other permeable materials from the Miocene period, and a deeper loamy 
layer which is impermeable. Aquifer IV.1 is characterized by the presence of two layers: a shallow permeable loamy layer from the Miocene period, and a deeper layer with sandy material cemented into conglomerate from the Pleistocene period (impermeable layer). Aquifer IV.2 is composed of detritus materials from the Pliocene period and reef limestones from Miocene-Pliocene periods located in the border areas. These materials are impermeable in depth, and on the top of this layer there is another layer of permeable volcanic rocks. Aquifer V.1 is composed of permeable quaternary fluvial materials, and is $13 \mathrm{~km}$ long, and $2 \mathrm{~km}$ wide. These materials are on top of a loamy layer from the Miocene and Pliocene periods, which constitutes the impermeable layer of the aquifer, and aquifer V.2 is composed of two layers: a shallow layer characterized by the presence of permeable materials such as gypsum and quartzite, and a deeper loamy layer which is impermeable.

Following the criteria established by CMAOT [13], the following aquifers have poor quality groundwater: III.4 because of its high concentration of $\mathrm{Cl}^{-}, \mathrm{Na}^{+}$and $\mathrm{K}^{+}$; IV.1 because of its high total organic carbon (TOC) value and $\mathrm{NO}_{3}{ }^{-}$and $\mathrm{SO}_{4}{ }^{2-}$ concentrations; IV.2 because of its high concentration of $\mathrm{Cl}^{-}$and $\mathrm{Na}^{+}$; $\mathrm{V} .1$ because of its high electrical conductivity (EC), value $\mathrm{NO}_{3}{ }^{-}, \mathrm{SO}_{4}{ }^{2-}$ and $\mathrm{K}^{+}$concentrations; and $\mathrm{V} .2$ because of its high concentration of $\mathrm{SO}_{4}{ }^{2-}$ (Table 4).

Table 4. Chemical composition of the groundwater in the aquifers beneath Almería [13].

\begin{tabular}{cccccc}
\hline \multirow{2}{*}{ Chemical Composition } & \multicolumn{5}{c}{ Aquifers } \\
\cline { 2 - 5 } & III.4 & IV.1 & IV.2 & V.1 & V.2 \\
\hline $\mathrm{COD}\left(\mathrm{mg} \mathrm{L}^{-1}\right)$ & $<15$ & $<15$ & $15.0-30.0$ & $<15$ & $<15$ \\
$\mathrm{TOC}\left(\mathrm{mg} \mathrm{L}^{-1}\right)$ & $4-11$ & $10-15$ & $4-7$ & $5-11$ & $6-8$ \\
$\mathrm{EC}\left(\mathrm{dS} \mathrm{m}^{-1}\right)$ & $0.5-2.7$ & $1.6-2.0$ & $3.5-5.1$ & $3.6-6.6$ & $0.8-1.0$ \\
$\mathrm{pH}$ & $7.5-8.1$ & $7.3-7.7$ & $7.0-8.4$ & $7.0-7.3$ & $7.4-7.6$ \\
$\mathrm{HCO}_{3}^{-}\left(\mathrm{mg} \mathrm{L}^{-1}\right)$ & $205-351$ & $218-359$ & $252-279$ & $270-340$ & $195-229$ \\
$\mathrm{CO}_{3}^{2-}\left(\mathrm{mg} \mathrm{L}^{-1}\right)$ & $<20$ & $<20$ & $<20$ & $<20$ & $<20$ \\
$\mathrm{Cl}^{-}\left(\mathrm{mg} \mathrm{L}^{-1}\right)$ & $478-815$ & $73-176$ & $997-1617$ & $500-660$ & $16-21$ \\
$\mathrm{NO}_{2}^{-}\left(\mathrm{mg} \mathrm{L}^{-1}\right)$ & $0.02-0.04$ & $0.02-0.04$ & $0.02-0.04$ & $0.02-0.05$ & $0.02-0.03$ \\
$\mathrm{NO}_{3}^{-}\left(\mathrm{mg} \mathrm{L}^{-1}\right)$ & $1-6$ & $9-25$ & $1-2$ & $65-100$ & $1-3$ \\
$\mathrm{PO}_{4}^{3-}\left(\mathrm{mg} \mathrm{L}^{-1}\right)$ & $0.05-0.06$ & $0.05-0.15$ & $<0.05$ & $0.05-0.08$ & $0.05-0.14$ \\
$\mathrm{SO}_{4}^{2-}\left(\mathrm{mg} \mathrm{L}^{-1}\right)$ & $38-188$ & $580-686$ & $241-603$ & $1487-1,897$ & $284-404$ \\
$\mathrm{Ca}^{2+}\left(\mathrm{mg} \mathrm{L}^{-1}\right)$ & $61-133$ & $208-229$ & $50-290$ & $487-690$ & $138-161$ \\
$\mathrm{Mg}^{2+}\left(\mathrm{mg} \mathrm{L}^{-1}\right)$ & $27-101$ & $85-109$ & $87-104$ & $159-188$ & $58-61$ \\
$\mathrm{Na}^{+}\left(\mathrm{mg} \mathrm{L}^{-1}\right)$ & $238-398$ & $72-167$ & $687-1,156$ & $412-546$ & $10-17$ \\
$\mathrm{~K}^{+}\left(\mathrm{mg} \mathrm{L}^{-1}\right)$ & $5-17$ & $2-5$ & $7-27$ & $21-37$ & $2.0-2.5$ \\
\hline
\end{tabular}

\section{Sustainable Technological Adaptation Trends}

Proper water resource management in a sustainable manner is one of the most crucial issues in order to meet food production demands and hence food safety. Nevertheless, the scarcity of water around the world, and especially in Almería, has resulted in the establishment of new sustainable technological adaptations. These technological adaptations can be classified as: (a) improvements in water use efficiency through automated fertigation, localized irrigation systems and the use of tensiometers; or (b) complementary sustainable systems such as recirculation, cascade cropping system and phytodepuration.

\subsection{Water Use Efficiency Improvements in Almería}

Irrigation management directly affects crop performance and can lead to qualitative and quantitative improvements in vegetable production [16]. Moreover, irrigation management needs to also be efficient in order to help reduce the environmental impact and promote the sustainable use of resources [17]. 


\subsubsection{Automated Fertigation Systems}

The practice of supplying crops with fertilizers through irrigation water is called fertigation. Fertigation is a modern agro-technique which provides an excellent opportunity to enhance yield and minimize environmental pollution by minimizing fertilizer application, increasing fertilizer use efficiency and increasing net returns on the investment in fertilizers [18].

The main advantages of this technique are the increased flexibility to split the fertilizer dose according to the uptake rate of the crop, an improved distribution of fertilizer in the root zone, the possibility of maintaining a low (but constant) nutrient level in the soil solution and the automation of fertilizer supplies. However, the major drawback of this technique is the higher investment cost [19].

Considering water scarcity in Almería, and the high market price of fertilizers, automatic control systems and management tools are fundamental in supplying water and nutrients at the required amount and frequency to any crop [20,21]. Fertigation control system requirements must be determined as a function of the desired crop performance, the irrigation and drainage water analyses, the soil/substrate nutrient content and the type of irrigation system [22].

Currently, $63 \%$ of greenhouses have automated fertigation systems allowing farmers greater control of irrigation parameters in the horticultural production system of the region [23]. Due to the implementation of this new technology, many studies have been carried out in order to determine the feasibility of this technique in this area. Morales and Urrestarazu [24] reported that the adjustment of a nutrient solution using an automated fertigation system increased productivity and decreased the environmental impact of the horticulture. Moreover, they concluded that there was a high uniformity in nutrient application for each plant with this technology. Similarly, Urrestarazu et al. [25] concluded that the use of automated fertigation systems in pepper and tomato crops resulted in an increase in nitrate and potassium plant uptake, and the consequent reduction of nitrate emissions to the environment. Rodriguez et al. [26] also studied the implementation of automatic fertigation systems in the horticultural system in Almería, concluding that this technology led to better water and nutrient use efficiencies in horticultural crops, so there was a saving in the inputs of this system.

\subsubsection{Localized Irrigation Systems}

Localized irrigation, or micro-irrigation, is widely adopted in greenhouse vegetables in Almería being used in $99.9 \%$ of the greenhouse surface area [27]. Micro-irrigation entails the slow and regular application of low-pressure ( $<2$ bar) water directly onto the root zone of the crops through a network of valves, pipes, tubing and emitters [28].

The main advantages of micro-irrigation systems are improvements in crop productivity through an efficient supply of water and nutrients which avoid inefficient losses, a reduction in workload, a high level of adaptability to changing geographic conditions and an improvement in the tolerance to salinity of a crop due to the slow and regular application of water. Nevertheless, the major drawbacks of micro-irrigation systems are the high investment costs and the risk of the clogging of emitters due to the precipitation of insoluble salts [29].

The main components of the micro-irrigation systems in Almería (Figure 3) are: (i) the irrigation/fertilization control center; (ii) the main pipelines and secondary lines; and (iii) the micro-tubes and emitters or diffusers. The irrigation control center is basically composed of filtering and fertilization equipment, pressure and flow control elements, and the automatic control equipment. The main and secondary pipelines, made of plastic materials (PVC or PE), carry the water towards the irrigation pipes (made from PE) to which the emitters or diffusers are connected, through which the water is supplied to the soil or substrate [5].

Many studies have been carried out under greenhouse conditions in Almería in order to determine the feasibility of the technology in this system. Fernandez et al. [30] carried out a survey concerning the irrigation performance in greenhouses in the region and they concluded that the farmers considered the implementation of this technology as an important source of water saving and high crop yield, which is essential in areas with water scarcity like Almería. Similarly, Alcon et al. [31] studied the adoption of 
drip irrigation technology in southeastern Spain during the period 1975-2005 and they concluded that the main benefit of this technology was saving water. Tarjuelo et al. [32] also studied the advantages of the implementation of micro-irrigation in greenhouses, reporting that there was an increase in water efficiency and productivity and an improvement in the operation and management of the working conditions of farmers. Finally, Sanchez et al. [33] studied the suitability of the micro-irrigation in greenhouse production in Almería concluding that one of the main reasons for the extensive development of this horticultural system was the establishment of this irrigation technology.

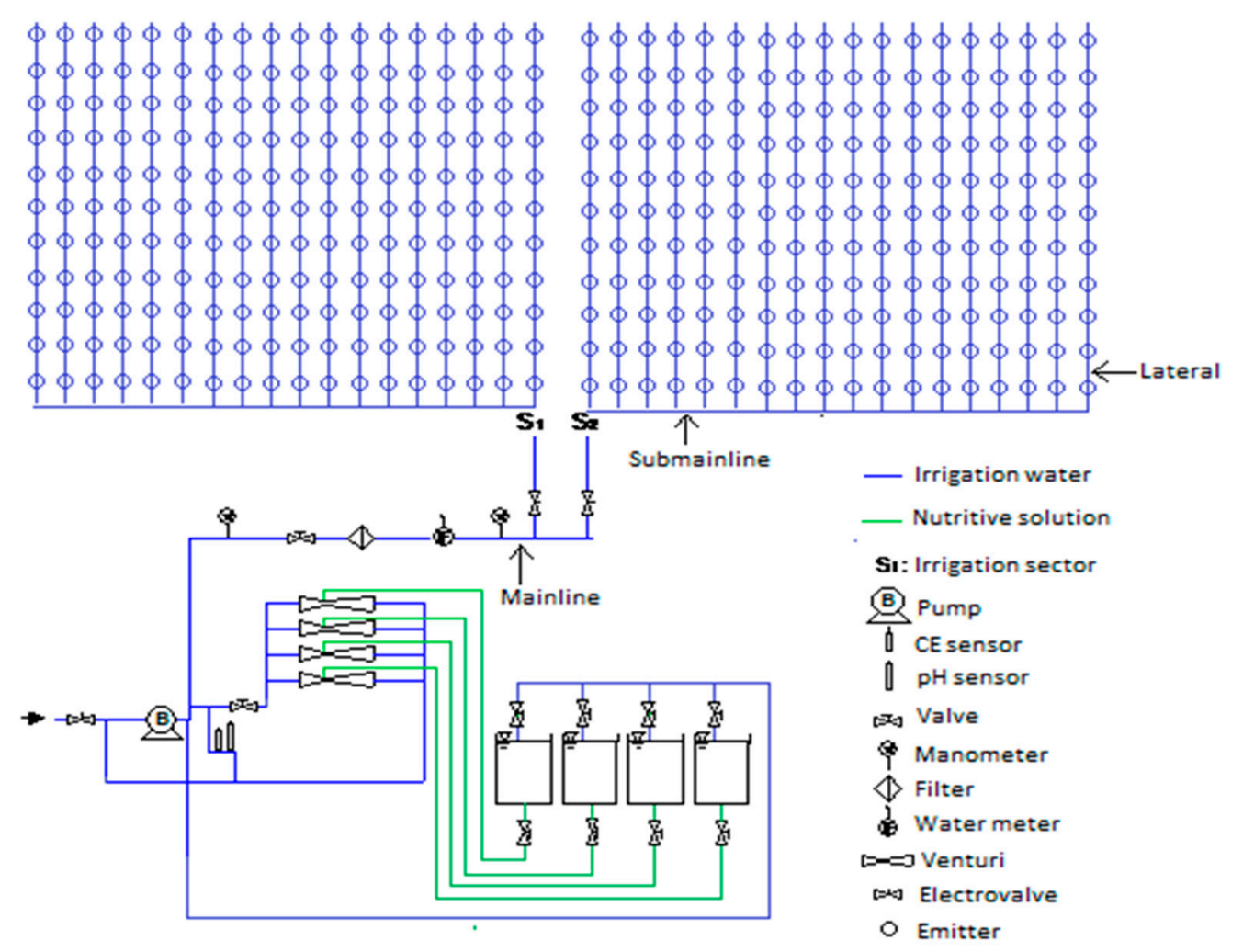

Figure 3. Scheme of fertigation and localized irrigation system in Almería (own resources).

\subsubsection{Tensiometers}

The use of tensiometers is increasing due to their easy management and economical cost, providing opportunities to integrate sensor networks into existing irrigation systems [34]. There are two types of tensiometers: manual tensiometers, where the data are obtained from the visual reading of a vacuum gauge, and electric tensiometers, where pressure traducers provide continuous measurements and can be used to directly activate irrigation [35].

The basic approach behind the automation of irrigation based on root-zone moisture measurements is simple: the moisture level in the growing media fluctuates according to evaporation and plant water use; sensors detect this change and automatically activate irrigation when the level reaches a set value predetermined by the operator, resulting in on-demand irrigation [36].

The main advantages of tensiometers are their low cost, simplicity of use, high accuracy, and direct measurement of matric potential. Also, they are not influenced by temperature and soil osmotic potential. Moreover, the installation of a set of tensiometers at increasing depths in the soil is a basic tool for assessing gradients of hydraulic heads and movements of soil water [37]. The major drawbacks of the use of tensiometers are that they must be carefully operated in order to avoid the formation of air bubbles in the shaft; they must be protected from frost, and they need regular maintenance, for instance, to refill the water in the tube [37]. 
From a practical point of view, the use of tensiometers requires the determination of the optimal matric potential for each crop and growing conditions in order to optimize water and nutrient use efficiency as reported by Buttaro et al. and Letourneau et al. [38,39]. Related to this, there is a lot of research being carried out under greenhouse conditions in Almería. Some research conducted by Lao and Jimenez [40] reported that rational management of fertigation through the use of tensiometers and suction cups can mitigate the pollution significantly, since there was a water saving of $22 \%$, and a reduction in $\mathrm{NO}_{3}{ }^{-}$supplies of $40 \%$ in greenhouse tomato crops. In another study, Thompson et al. [41] studied the thresholds of soil matric potential through the use of tensiometers to prevent water limitations between irrigations in bell pepper, melon and tomato grown in greenhouses on the south-eastern coast of Spain. They concluded that the soil matric potential thresholds were $-58 \mathrm{kPa}$ for pepper, $-35 \mathrm{kPa}$ for melon and $-38 \mathrm{kPa}$ for tomato. Researching the cultivation of watermelon and green beans irrigated through the use of tensiometers, Gonzalez et al. [42] reported that the soil matric potential should be between -20 and $-30 \mathrm{kPa}$ in order to avoid water deficits in these crops. Moreover, they concluded that the growers can use the technique of managing the soil matric potential to control the equilibrium between the vegetative and reproductive growth of greenhouse crops. Jimenez et al. [43] carried out an experiment with tomato plants irrigated through the use of tensiometers. They reported a decrease in water consumption and higher nutrition use efficiencies without a yield reduction. In this sense, they concluded that the use of tensiometers allows horticultural crops to be grown using less water, fewer fertilizer inputs and causing less environmental damage. Finally, Contreras et al. [44] reported that maintaining soil matric potential at a pressure between -15 and $-25 \mathrm{kPa}$ yielded a significant reduction in water volume and nutrients used, compared to a soil matric potential of $-10 \mathrm{kPa}$ in zucchini crops.

Summarizing all of these improvements, although they are not fully embedded, it is necessary to highlight the high values of water use efficiency in horticultural crops in Almería. Zucchini is the horticultural crop with the highest water use efficiency $\left(37.6 \mathrm{~kg} \mathrm{~m}^{-3}\right)$ and green bean has the lowest water use efficiency $\left(4.1 \mathrm{~kg} \mathrm{~m}^{-3}\right)$ (Table 5) [8].

Table 5. Water use efficiency (expressed in $\mathrm{kg}$ of fruit per $\mathrm{m}^{3}$ of water applied) under greenhouse conditions of the horticultural crops grown in Almería [8].

\begin{tabular}{cc}
\hline Horticultural Crop & Water Use Efficiency \\
\hline Pepper & 20.7 \\
Tomato & 20.3 \\
Cucumber & 37.6 \\
Zucchini & 28.3 \\
Eggplant & 13.7 \\
Green bean & 4.1 \\
Watermelon & 20.1 \\
Melon & 10.1 \\
\hline
\end{tabular}

\subsection{Complementary Sustainable Systems}

There have been many studies carried out in Almería concerning the pollution generated by the horticultural production system. It is estimated that the supply of fertilizer (N-P-K) ranges from 2000 to $3400 \mathrm{~kg} \mathrm{ha}^{-1}$ per crop, and that the discharge of leachate ranges from 20 to $50 \%$ of the initial supply [45]. For instance, Lao and Jimenez [40] reported $46 \%$ and $58 \%$ of water and $\mathrm{NO}_{3}{ }^{-}$, respectively, leached in a tomato greenhouse crop (246 DAT) grown with traditional management in a mulched sandy soil (Table 6). Also, Plaza et al. [46,47] reported $34 \%$ and $39 \%$ of water and $\mathrm{NO}_{3}{ }^{-}$, respectively, leached with watermelon grown in rockwool (80 DAT), and Garcia-Caparros et al. [48] reported 28\% and $17 \%$ of water and $\mathrm{NO}_{3}{ }^{-}$, respectively, leached with melon grown in perlite (91 DAT) (Table 7). These results show the high degree of the pollution generated by the horticultural production system. 
Due to this problematic situation, it is essential to search for complementary sustainable systems such as recirculation, cascade cropping and phytodepuration, which have been recognized as promising solutions for addressing the problem of pollution worldwide. Thus, the adoption of these systems will ensure the implementation of leachate reuse between farmers from intensive horticultural production systems.

Table 6. Volume of water (expressed in $\mathrm{L} \mathrm{m}^{-2}$ ) and nutrients supplied (SN) and leached (SL) (expressed in $\mathrm{g} \mathrm{m}^{-2}$ ), and the percentage of water and nutrients leached with respect to the water and nutrients supplied (\%) in a tomato greenhouse crop [40].

\begin{tabular}{cccc}
\hline & SN & SL & $\%$ \\
\hline Water & 351.4 & 163.3 & 46 \\
$\mathrm{NO}_{3}{ }^{-}$ & 212.7 & 123.7 & 58 \\
$\mathrm{H}_{2} \mathrm{PO}_{4}{ }^{-}$ & 47.3 & 3.3 & 7 \\
$\mathrm{~K}^{+}$ & 72.1 & 6.4 & 9 \\
$\mathrm{Ca}^{2+}$ & 38.9 & 54.2 & 139 \\
$\mathrm{Mg}^{2+}$ & 41.3 & 46.9 & 114 \\
$\mathrm{SO}_{4}^{2-}$ & 89.6 & 95.4 & 106 \\
$\mathrm{Na}^{+}$ & 163.5 & 139.6 & 85 \\
$\mathrm{Cl}^{-}$ & 280.8 & 246.1 & 88 \\
\hline
\end{tabular}

Table 7. Volume of water (expressed in $\mathrm{L} \mathrm{m}^{-2}$ ) and nutrients supplied (SN) and leached (SL) (expressed in $\mathrm{g} \mathrm{m}^{-2}$ ), and the percentage of water and nutrients leached with respect to the water and nutrients supplied (\%) in watermelon [46,47] and melon [48].

\begin{tabular}{ccccccc}
\hline & \multicolumn{3}{c}{ Watermelon } & \multicolumn{3}{c}{ Melon } \\
\cline { 2 - 7 } & SN & SL & \% & SN & SL & \% \\
\hline Water & 215.0 & 73.8 & 34 & 254.3 & 71.3 & 28 \\
$\mathrm{NO}_{3}{ }^{-}$ & 190.0 & 73.3 & 39 & 149.9 & 26.1 & 17 \\
$\mathrm{H}_{2} \mathrm{PO}_{4}{ }^{-}$ & 18.1 & 4.1 & 23 & 34.5 & 0.1 & 0 \\
$\mathrm{~K}^{+}$ & 41.2 & 15.9 & 38 & 48.4 & 6.9 & 14 \\
$\mathrm{Ca}^{2+}$ & 42.4 & 16.8 & 40 & 52.3 & 40.7 & 78 \\
$\mathrm{Mg}^{2+}$ & 52.8 & 25.5 & 48 & 9.7 & 10.2 & 105 \\
$\mathrm{SO}_{4}^{2-}$ & 157.4 & 66.1 & 42 & 54.5 & 14.5 & 27 \\
$\mathrm{Na}^{+}$ & 103.2 & 46.1 & 45 & 15.2 & 18.6 & 123 \\
$\mathrm{Cl}^{-}$ & 35.0 & 19.0 & 54 & 31.1 & 41.6 & 134 \\
\hline
\end{tabular}

\subsubsection{Recirculation}

Hydroponics culture is any method of growing plants without the use of soil as a rooting medium [49]. This relatively simple definition encompasses a diverse range of plant growth systems which generally involve containerization of plant roots within a porous rooting medium known as a 'substrate' or 'growing medium' [50]. Compared with soil-based cultivation, hydroponics culture can be more cost-effective [51], producing higher yields and prompter harvests from smaller areas of land [52,53]. Hydroponics culture also has generally higher water and nutrient use efficiencies [54,55].

Closed-cycle management of hydroponics culture, with recycling of nutrient solutions, is one of the promising strategies aiming at minimizing pollution [56] and increasing water and fertilizer-use efficiency in irrigated greenhouse agriculture [57]. However, although in particular productive areas, the adoption of a closed-cycle system is a well-established practice (e.g., The Netherlands), commercial application of these systems is scarce in areas with low technology greenhouses (such as the Mediterranean basin), as their management is more complex compared with open (free-drainage) cultivation systems [58].

Closed systems are classified as: (a) Nutrient Film Technique (NFT), where the nutrient supply to the roots is provided by a thin film of nutrient solution streaming around the roots. This provides a 
good contact between the recirculating solution and air, which is sufficient to maintain the oxygen level required by the roots without additional aeration of the solution. Since the solution is continually moving, there is very little short-term variation in salinity, unlike in soil, where salinity rises and falls with the water content. This allows the growth of plants at a higher salinity in NFT solutions than in soil-based production [59]. A typical NFT system for Almería, developed in the 1990s, is the New Growing System (NGS), having several potential advantages such as the high oxygen concentration in the root-zone [60]; A second closed growing system is (b) growth in substrate, where the plant roots may grow in porous media (substrates), which are frequently irrigated with a nutrient solution, while a third system is (c) Deep Flow technique (DFT) with plants growing directly in the nutrient solution without any solid phase. In recent decades, supplying a nutrient solution to plants to optimize crop nutrition (fertigation or liquid fertilization) has become routine cultural practice, not only in soilless culture but also in soil-grown greenhouse crops. Hence, the drastically restricted volume of the rooting medium, and its uniformity, are the only characteristics of hydroponics culture differentiating them from crops grown in the soil [49]. In Almería, soilless plant culture is less than $8 \%$ of the total surface of greenhouses, and recirculation is anecdotic in Almería [9,23]. Nevertheless, there has been a lot of research carried out in greenhouses in Mediterranean climatic conditions to determine the feasibility of growing horticultural crops under these conditions. Magan et al. [61] carried out an experiment with recirculation on nutrient solution in two cultivars of tomato plants, and they reported that there was a relationship between the increase in the electrical conductivity in the nutrient solution used for recirculation and the decrease in fruit yield in both cultivars. Similarly, Rodriguez et al [62] studied the use of recirculation for the growth of tomato plants, and they reported a high water saving and a reduction in fruit yield.

\subsubsection{Cascade Cropping Systems}

The cascade cropping system is a sequence of fields within the boundaries of a farm, or an irrigation district, which are irrigated with saline water that is collected as subsurface drainage, or runoff, from a larger area of the farm, or from several farms [63]. One of the main models of this technique is the IFDM (Integrated Farm Drainage Management) system which was applied in California from 2003 on a culture surface of 63,000 ha. The general IFDM presents five areas with five different stages: sensitive saline crop, tolerant saline crop, resistant salinity crop, halophytic crop and pond for evaporation [64].

One approach of this strategy is the Serial Biological Concentration (SBC) [65]. The SBC concept was initially proposed to minimize drainage water with high selenium contents in the San Joaquin Valley, California [66]. This system involves the process of irrigating crops in a series of increasing crop salt tolerance [67], where the drainage water collected from beneath one crop is used to irrigate the next more salt tolerant crop in the series. The number of stages used in the design of SBC systems would vary according to the soil and irrigation water salinity, as well as the salt tolerance of the plants used in the system [68].

For the implementation of this system under greenhouse conditions in Almería, in-depth knowledge of the chemical composition and the volume of leachates generated by all the horticultural species cultivated in this region is necessary. Moreover, it is necessary to know the salt tolerance degree of crops (horticultural and ornamental) involved in the cascade system production.

Related to this, there has been some research carried out in Almería comparing a cascade cropping system against a conventional cropping system under greenhouse conditions from an agronomic and environmental point of view. In one of these pieces of researches, using Citrullus lanatus and Cordyline fruticosa plants, the use of $C$. lanatus leachate to irrigate $C$. fruticosa yielded a reduction in the supply of water and $\mathrm{NO}_{3}{ }^{-}$to the latter plant from $35.5 \mathrm{~L} \mathrm{~m}^{-2}$ and $14.9 \mathrm{~g} \mathrm{~m}^{-2}$, respectively, to $0 \mathrm{~L} \mathrm{~m}^{-2}$ and $0 \mathrm{~g} \mathrm{~m}^{-2}$. From an environmental point of view, there was a saving of water and a reduction in pollution under cascade cropping system [69]. 
Another study of these systems was carried out with native plants from the Mediterranean basin: Ruscus aculeatus, Maytenus senegalensis and Juncus acutus in a cascade closed system. The use of $R$. aculeatus and $M$. senegalensis leachate to irrigate J. acutus yielded a reduction in the supply of water and $\mathrm{NO}_{3}{ }^{-}$to the latter plant from $22.1 \mathrm{~L} \mathrm{~m}^{-2}$ and $8.9 \mathrm{~g} \mathrm{~m}^{-2}$, respectively, to $0 \mathrm{~L} \mathrm{~m}^{-2}$ and $0 \mathrm{~g} \mathrm{~m}^{-2}$. In this assay, there was a saving of water and the level of pollution was reduced under the cascade cropping system because the drainage of the system was zero [70].

Following the same line of study, García-Caparros et al., 2017 [48] carried out a trial with Cucumis melo, Rosmarinus officinalis and Cacti spp. plants in a cascade closed system. The results reported that the use of $C$. melo and R. officinalis leachate to irrigate Cacti spp. yielded a reduction in the supply of water and $\mathrm{NO}_{3}{ }^{-}$to the latter plant from $5.9 \mathrm{~L} \mathrm{~m}^{-2}$ and $4.4 \mathrm{~g} \mathrm{~m}^{-2}$, respectively, to $0 \mathrm{~L} \mathrm{~m}^{-2}$ and $0 \mathrm{~g} \mathrm{~m}^{-2}$. Concerning the level of pollution, this trial showed the same results as mentioned in the previous trial, since the drainage of the system was zero.

These interesting results show that the cascade cropping system is a useful tool to decrease the scarcity of natural water resources and water and soil pollution according to an economic development. Currently, these results are being passed onto commercial growers in Almería.

\subsubsection{Phytodepuration}

Phytodepuration technologies are an alternative to conventional methods of wastewater treatment [71]. These technologies are based on natural processes involving vegetation, soils and associated microbial assemblages to treat wastewaters [72]. The most common engineered systems are the so-called constructed wetlands. They are a cost-effective, extensive, efficient and eco-friendly wastewater treatment technology that has been growing over the last few decades [73].

Constructed wetlands are designed and constructed to mimic natural wetland systems for treating wastewater. These systems, mainly comprised of vegetation, substrates, soils, microorganisms and water, utilize complex processes involving physical, chemical, and biological mechanisms to remove various contaminants and/or improve the water quality [74].

Constructed wetlands are classified into two groups, based on the predominant position of water in the systems: those with surface flow above a benthic substrate, and those with subsurface flow through a porous media. The systems with surface flow are divided into three standard types, differentiated by vegetation type: Surface Flow (SF), Free-Floating Macrophyte (FFM), and Floating Emergent Macrophyte (FEM). Subsurface flow systems always contain sessile emergent macrophytes and are divided into four standard types, based on flow direction: Horizontal Flow (HF), Down Flow (DF), Up Flow (UF) and Fill and Drain (FaD) [75].

In constructed wetlands, the use of macrophytes plays an essential role, due to its nutrient capacity and heavy metal removal. Frequently used macrophytes include emergent plants, submerged plants, floating leaved plants and free-floating plants. Although more than 150 macrophyte species have been used in constructed wetlands globally, only a limited number of these plant species are usually planted in constructed wetlands in reality [76].

Many studies have been carried out throughout the world on constructed wetlands for secondary or even tertiary treatment of various types of wastewaters, such as municipal wastewaters $[77,78]$ and storm-water $[79,80]$. As far as agricultural runoff is concerned, there are many studies worldwide about the feasibility of constructed wetlands to reduce the pollution of agricultural runoff [81-85]. Nevertheless, this promising technology is still incipient, currently there are very few references concerning its implementation in the horticultural production system in Almería. One such study, was the experiment carried out by García-Caparros et al. [86] where J. acutus plants were used in a constructed wetland in order to reduce the pollution generated by leachates discharged by other ornamental plants. 


\section{Alternative Water Resources in Almería}

The shortage of water supplies for irrigation purposes is already a very serious problem in Almería. For the entire Mediterranean region, conservative estimates indicate a water shortage of about 10 million $\mathrm{m}^{3}$ day $^{-1}$ by the year $2020[87,88]$. As a solution to this problem, seawater desalination and reclaimed water for sustaining agricultural production are being reported as alternative water resources in the horticultural production system of the area.

\subsection{Desalinated Water}

Desalination is the process of producing fresh water from saline water. If the source of water is seawater, the process is called desalination, and when it comes from brackish continental water it is called desalobration. The process of desalination is performed through different technologies such as evaporation, distillation, ionic exchange and reverse osmosis. Desalination has become an important source of water for agricultural irrigation worldwide, with thermal desalination processes developing over the past 60 years, and membrane processes developing over the past 40 years. Today, reverse osmosis (RO) is the leading technology for new desalination installations, with a $44 \%$ share in world desalting production capacity and an $80 \%$ share in more than 15,000 desalination plants installed worldwide [89].

The method of seawater capture for supplying reverse osmosis desalination plants is a key factor in determining the cost of the desalinated water, and a significant factor influencing the useful life of the membranes and the plant as a whole [90]. The two abstraction methods most commonly used are open seawater intake and beach well systems [91].

Direct seawater intake is the most widely used technique since it requires a relatively simple and cheap infrastructure, and is capable of delivering large seawater flows to the plant. The main drawback of this abstraction method is that water quality is usually poor due to high concentrations of organic matter and dissolved oxygen, and has an elevated silt density index, which generally exceeds the values recommended by the manufacturers of the reverse osmosis membranes [91].

An alternative method is to use coastal boreholes (beach wells), which offer the possibility of supplying better quality water to the desalination plant: the aquifer formation filters the water before it reaches the plant, so reducing pre-treatment costs. The technique consists of sinking a battery of boreholes into a coastal aquifer in order to make abstractions from the seawater wedge that penetrates beneath the fresh water in the aquifer [92,93].

Nowadays, in Almería there are six desalination plants with a total water capacity of $141 \times 10^{6} \mathrm{~m}^{3}$ per year. The Carboneras desalination plant supplies $30 \%$ of the desalinated water in the area, followed by the desalination plants of Campo de Dalias (21\%), Rambla Morales (16\%) and Bajo Almanzora (14\%) (Table 8) [94].

Table 8. Water capacity in the desalination plants using reverse osmosis in Almería [94].

\begin{tabular}{|c|c|}
\hline Desalination Plants & Water Capacity $\left(10^{6} \mathrm{~m}^{3}\right.$ Per Year) \\
\hline Bajo Almanzora & 20 \\
\hline Palomares & 9 \\
\hline Carboneras & 42 \\
\hline Rambla Morales & 22 \\
\hline Almería & 18 \\
\hline Campo de Dalias & 30 \\
\hline Total & 141 \\
\hline
\end{tabular}

The major drawbacks of the use of desalination are the strong likelihood of detrimentally impacting both the physicochemical and ecological attributes of the receiving environments, such as the increase in temperature or the alteration of benthic communities [95], as well as the high-energy 
consumption and $\mathrm{CO}_{2}$ emissions $[96,97]$. Nevertheless, the use of solar energy could make the system more sustainable.

The use of desalinated water for irrigation presents advantages such as the good chemical quality and the continuousness of supply. In an experiment in the east of Spain with orange trees, Zarzo et al. [98] found a yield increase compared to the use of other available types of waters, such as surface water with an electrical conductivity (EC) ranging from 1.2 to $2.2 \mathrm{dS} \mathrm{m}^{-1}$, and brackish groundwater EC ranging from 5.0 to $7.0 \mathrm{dS} \mathrm{m}^{-1}$. Valera et al. [99] also reported a higher fruit yield, but lower organoleptic quality for horticultural crops in greenhouses irrigated with desalinated water in the area of Nijar and Bajo Andarax compared to conventional (underground) high salinity water $\left(7.47 \mathrm{dS} \mathrm{m}^{-1}\right)$ for tomato and watermelon crops, and mid-level salinity $\left(2.36 \mathrm{dS} \mathrm{m}^{-1}\right)$ for a pepper crop.

Among farmers, there is a contrasting view, because they consider the need for additional fertilization as an extra cost involved in the irrigation management of greenhouse crops due to the low concentration of nutrients in the desalinated water compared to groundwater [100].

\subsection{Reclaimed Water}

The use of reclaimed water can provide an important quantity of nutrients, especially $\mathrm{N}$ and $\mathrm{P}$, which can increase soil fertility and benefit plant growth and crop production, reducing the quantity of commercial fertilizers needed and thus increasing the farmers' economic benefits. Nevertheless, its nutrient content and the nutrient demand of the crops need to match in order to achieve these benefits [101]. The use of reclaimed water involves major disadvantages as it can lead to the accumulation of heavy metals in the soil and to the transmission of pathogens [102]. The accumulation of these heavy metals, which are carcinogenic, as well as their oxidized derivatives can lead to the pollution of the water and the generation of genotoxicity [103].

In Almería, the first studies to reuse reclaimed water for irrigation in agriculture began in the 1980s and focused on the collection of effluents and water disinfection treatments [104]. The results derived from these investigations, together with other experiences developed outside the province, determined that the most suitable solution for the treatment of these effluents was ozonation. This technique has been shown to be more effective when disinfecting against viruses, bacteria and fungi than other disinfectants such as chlorine, hypochlorous acid or chlorine dioxide [105].

In more recent works, García-Delgado et al. [106] studied the effects of different disinfection systems, such as purification, chlorination and chlorination plus ozonation on the mineral content in reclaimed water, concluding that disinfection treatments did not affect macronutrient and micronutrients levels in reclaimed water. Moreover, Martinez et al. [107] investigating the effects of ozone on wastewater treatment, concluded that ozone disinfection treatment was sufficient to inactivate faecal coliforms.

Currently, the implementation of reclaimed water in irrigation for agricultural production in Almería is now taking place. Many agronomic studies have been conducted in the greenhouses in this region in order to determine the feasibility of this type of water in horticultural crops. For instance, Segura et al. [108] investigated the fertilizer effect of the use of ozonized reclaimed water on pepper production, fruit quality and soil fertility compared to the use of groundwater. They reported no differences in yield, biomass and quality index in plant and fruits between both types of water, but the use of ozonized reclaimed water resulted in a saving in nutrients $(\mathrm{N}(37 \%), \mathrm{P}(66 \%)$ and $\mathrm{K}(12 \%)$, respectively). Similar results were obtained by Martinez et al. [109] in a melon crop, where the use of ozonized reclaimed water resulted in a saving in $\mathrm{N}$ and $\mathrm{K}$ supplies $(\mathrm{N}(63 \%)$ and $\mathrm{K}(21 \%)$, respectively). The feasibility of reclaimed water in salinity sensitive crops, such as green beans, has also been studied by Segura et al. [110], establishing an optimal dose of $\mathrm{N}$ and $\mathrm{K}$ for this crop in order to improve the productivity and nutrient use efficiency. The optimal dose was $47 \mathrm{~kg} \mathrm{ha}^{-1}$ of $\mathrm{N}$ and $23 \mathrm{~kg} \mathrm{ha}^{-1}$ of K over the crop cycle. Finally, from a legislative point of view, it is necessary to point out that the use of reclaimed water is regulated by the European Directive of Water (Directive 2000/60/CE). In this 
framework, Spanish legislation is developed in the National Hydrological Plan (Ley 11/2005 and Real Decreto 1620/2007).

\subsection{Integral Management of Water Resources}

Considering the alternative water resources already mentioned, the integral management of water resources occurs frequently in greenhouses in Almería; however, it is essential that the water mixtures have suitable characteristics for use in horticultural crops [111].

To achieve the appropriate water mixture for use in horticulture it is necessary to avoid uncontrolled oscillations in water quality, since these oscillations can negatively affect crop management, especially in relation to fertigation. As a consequence, in the majority of installations, the fertilizer balance is adjusted just by controlling the electrical conductivity of the irrigation solution [23].

Currently, there are two strategies to manage the mixtures of different water resources: (a) common mixture, in which the irrigation community manages the mixture in such a way that all farmers will have the same water quality; and (b) different water source supplies (Figure 4), in which the farmer has the different water sources on his own farm and he/she manages the final mixture and chooses the quality according to the needs of the crop [112].

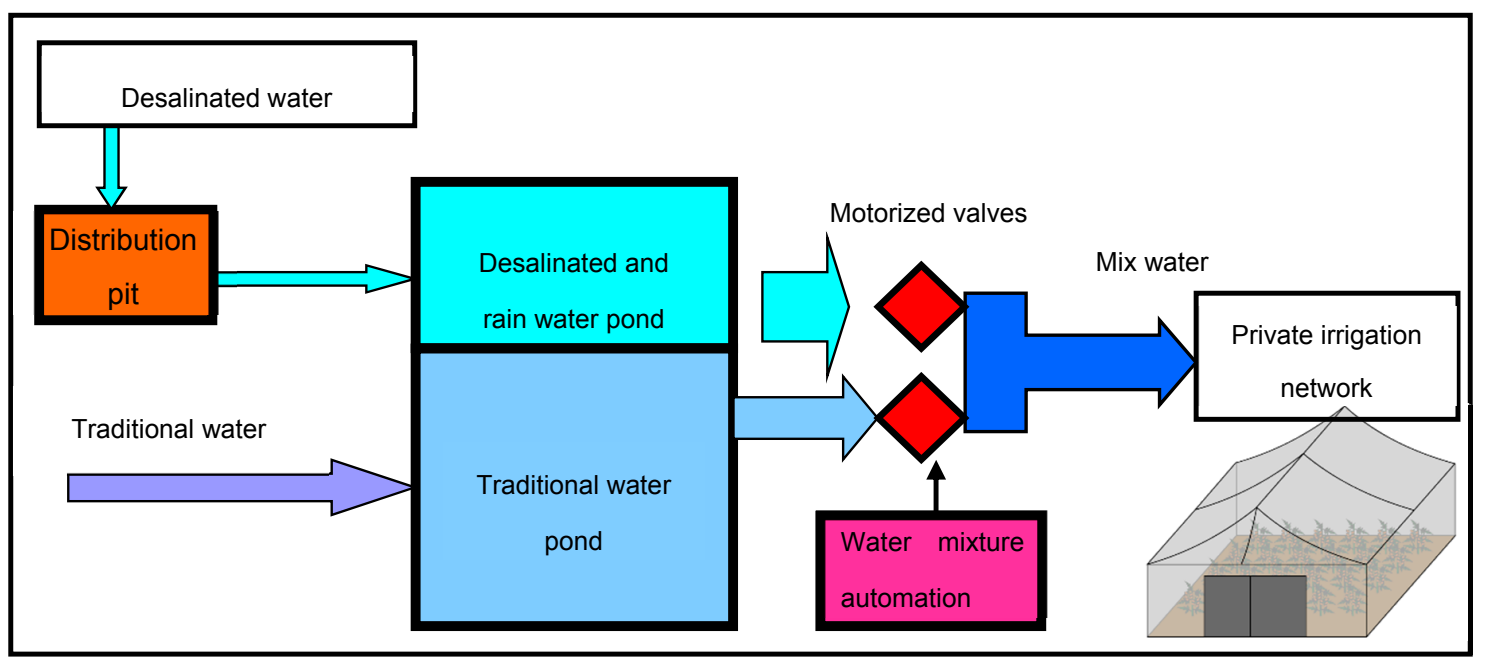

Figure 4. Scheme of the facilities necessary for the handling of different water source supplies (own resources).

In both cases, storage, transport and mixing infrastructures are needed. However, the cost is usually higher for the second strategy which offers different water sources at farm level, since it duplicates the transport and storage infrastructure. An important advantage of the mixtures at the farm level is the monitoring of collected waters used for the fertigation [112].

In Almería, currently, common mixtures are being used in the Campo de Dalias region, different water source supplies at farm level are present in Campo de Nijar, and both water management strategies are used in Bajo Andarax [112]. However, the review by Zarzo et al. [98] on the Spanish experience with desalination for agriculture did not mention any concrete experience with desalinated water as a component of mixed waters for agricultural irrigation.

Several personal communications from managers of irrigation communities in Almería show that in recent years the mixture of desalinated water with water of continental origin has begun. However, there is no specific monitoring of the use of these mixtures of waters in the greenhouses in Almería [98]. Due to the lack of information, nowadays there are several lines of work to define mixtures in order to achieve a high agronomical and economic efficiency in the greenhouse conditions in the region. 


\subsection{Water Balances Including Alternative Water Resources}

Table 9 shows the water balances in each river basin including alternative water resources such as desalinated and reclaimed water. Concerning the desalinated water, river basins III.4 and V.1 have the highest input, whereas for reclaimed water, river basin III.4 has the highest input [13]. These results reported that only two river basins are overexploited, which means that the use of alternative water resources may be a sustainable tool for the intensive horticulture system in Almería.

Table 9. Water balance including alternative water resources, irrigation consumption and horticultural water exploitation index in the river basins of Almería [13].

\begin{tabular}{|c|c|c|c|c|c|c|}
\hline $\begin{array}{l}\text { River } \\
\text { Basin }\end{array}$ & $\begin{array}{c}\text { Surface and } \\
\text { Groundwater }\left(10^{6} \mathrm{~m}^{3}\right)\end{array}$ & $\begin{array}{l}\text { Desalination } \\
\qquad\left(10^{6} \mathrm{~m}^{3}\right)\end{array}$ & $\begin{array}{c}\text { Reclaimed } \\
\text { Water }\left(10^{6} \mathrm{~m}^{3}\right)\end{array}$ & $\begin{array}{c}\text { Total } \\
\left(10^{6} \mathrm{~m}^{3}\right)\end{array}$ & $\begin{array}{l}\text { Irrigation Consumption } \\
\qquad\left(10^{6} \mathrm{~m}^{3} \text { year }^{-1}\right)\end{array}$ & $\begin{array}{l}\text { Horticultural Water } \\
\text { Exploitation Index }\end{array}$ \\
\hline III. 4 & 147.1 & 30 & 8.4 & 185.5 & 168.3 & 0.9 \\
\hline IV.1 & 45.0 & 6.7 & 8 & 59.7 & 44.1 & 0.7 \\
\hline IV. 2 & 11.6 & 0 & 0.5 & 12.1 & 34.3 & 2.8 \\
\hline V.1 & 10.1 & 19.2 & 0 & 29.3 & 21.2 & 0.7 \\
\hline V.2 & 45.1 & 9.3 & 1.1 & 55.5 & 85.9 & 1.5 \\
\hline Total & 258.9 & 65.2 & 18.0 & 342.1 & 353.8 & 1.0 \\
\hline
\end{tabular}

\subsection{Economic Study of Water Resources}

Nowadays, there is a reduction in the price of desalinated water mainly due to a reduction in energy consumption and the maintenance costs of desalinated plants; years ago energy consumption was $20 \mathrm{kWh} \mathrm{m}^{-3}$, and nowadays it is $3 \mathrm{kWh} \mathrm{m}^{-3}$. The actual price of desalinated water, including implementation and management costs, ranges from 0.40 to $0.60 € \mathrm{~m}^{-3}$ depending on the source of the desalinated water. This cost can be itemized into different factors: $43 \%$ energy, 37\% amortization expenses, and the remaining 20\% maintenance and manpower costs [113].

On the other hand, the cost of depuration of reclaimed water is around $0.220 € \mathrm{~m}^{-3}$, which can be itemized into the following factors: manpower $0.088 € \mathrm{~m}^{-3}(40 \%)$, energy $0.042 € \mathrm{~m}^{-3}(19 \%)$, waste treatment $0.035 € \mathrm{~m}^{-3}(16 \%)$, maintenance $0.026 € \mathrm{~m}^{-3}(12 \%)$ and others $0.029 € \mathrm{~m}^{-3}(13 \%)$. Moreover, there are additional costs in the price of reclaimed water, the first is the distribution cost, around $0.100 € \mathrm{~m}^{-3}$, and the latter is based on the treatment used on the reclaimed water, since the cost of a secondary treatment is $0.260 € \mathrm{~m}^{-3}$, tertiary treatment $0.060 € \mathrm{~m}^{-3}$ and more advanced treatments $0.06 € \mathrm{~m}^{-3}$. Considering all of these factors, the price of reclaimed water for the farmer ranges from $0.360 € \mathrm{~m}^{-3}$ to $0.560 € \mathrm{~m}^{-3}$ depending on the chemical treatment used on the reclaimed water [114]. Nowadays, due to environmental concern about water scarcity in Spain, the government is offering grants to the farmers in order to promote the use of reclaimed water, therefore the actual prices, including the grants, ranges from 0.30 to $0.40 € \mathrm{~m}^{-3}$ [114].

The price of groundwater, including distribution for the irrigation of horticultural crops, depends on the depth of the aquifers and the consequent energy cost for its extraction. This price ranges from 0.06 to $0.12 € \mathrm{~m}^{-3}$ [114]. Both reclaimed water and desalinated water do not require any special adaptation for their use in automated fertigation systems, which is an advantage for the farmers. As far as price is concerned, the use of alternative water resources (reclaimed and desalinated water) is very expensive, but using reclaimed water is cheaper than using desalinated water. However, the perception among farmers in the region is that the high cost of these alternative water resources could be accommodated, since although this highly productive horticultural system demands a great amount of water resources, the cost of this input could be solved with higher yields [100].

\section{Conclusions}

According to this study, the intensive greenhouse horticultural production system in Almería has been shown to be an economically and environmentally sustainable system with respect to the efficient use of water resources. Almería presents several water systems with a water exploitation index close 
to 1 , however this is likely to increase soon. So, other measures, such as the use of desalinated and reclaimed water will be necessary to maintain sustainable water use.

Complementary sustainability techniques such as recirculation, cascade and phytodepuration systems are only in an initial phase and deserve further development, as they can solve several items of environmental impact.

Finally, high water use efficiency is being achieved due to the implementation of a wide range of equipment and technologies such as automated fertigation, localized irrigation systems and the management of fertigation through tensiometers.

Acknowledgments: Irrigation Technology Transfer Project. Operational Program of Andalusia 2014-2020. European Regional Development Fund (ERDF) Cod. PP. TRA. TRA201600.3. Sustainable Development in Protected Horticultural Crops. Operational Program of Andalusia 2014-2020. European Regional Development Fund (ERDF) Cod. PP. TRA. TRA201600.9.

Author Contributions: The authors contributed equally to this work.

Conflicts of Interest: The authors declare no conflict of interest.

\section{Abbreviations}

The following abbreviations are used in this manuscript:

$\begin{array}{ll}\text { COD } & \text { Chemical oxygen demand } \\ \text { EC } & \text { Electrical conductivity } \\ \text { EEA } & \text { European Environment Agency } \\ \text { IFDM } & \text { Integrated Farm Drainage Management } \\ \text { RO } & \text { Reverse osmosis } \\ \text { SBC } & \text { Serial Biological Concentration } \\ \text { TOC } & \text { Total organic carbon } \\ \text { WUE } & \text { Water use efficiency }\end{array}$

\section{References}

1. CAPDR. Cartografía de Invernaderos en Almería, Granada y Málaga; Consejeria de Agricultura, Pesca y Desarrollo Rural: Andalucia, Spain, 2017.

2. Contreras, J.I.; Plaza, B.M.; Lao, M.T.; Segura, M.L. Growth and nutritional response of melon to water quality and nitrogen and potassium levels under greenhouse Mediterranean conditions. Commun. Soil Sci. Plant Anal. 2012, 43, 434-444. [CrossRef]

3. Cabrera, A.; Ucles, D.; Aguera, T.; de la Cruz, E. Análisis de la Campaña Hortofrutícola de Almería Campaña 2015/2016; Cajamar Caja Rural: Almería, Spain, 2016.

4. Langle, G. Diagnosis for the Design and Implementation of a Crisis Manual in the Horticultural Export Industry of Almería. Master's Thesis, University of Almería, Almería, Spain, 2012.

5. Castilla, N.; Baeza, E.J.; Papadopulos, A.P. Greenhouse Technology and Management, 2nd ed.; CAB International: Oxfordshire, UK, 2013.

6. Montero, J.I.; Teitel, M.; Baeza, E.; Lopez, J.C.; Kacira, M. Greenhouse design and covering materials. In Good Agricultural Practices for Greenhouse Vegetable crops: Principles for Mediterranean Climate Areas; Paper 217; FAO, Plant Production and Protection: Rome, Italy, 2013; pp. 35-62.

7. Nisen, A.; Grafiadellis, M.; Jiménez, R.; La Malfa, G.; Martínez-García, P.F.; Monteiro, A.; Verlodt, H.; Villele, O.; Zabeltitz, C.H.; Denis, J.C.; et al. Cultures Protegees en Climat Mediterraneen; FAO: Rome, Italy, 1988; 335p, ISBN 92-5-202719-X.

8. Tolón, A.; Lastra, X. La agricultura intensiva del poniente almeriense. Diagnóstico e instrumentos de gestión ambiental. Revista Electrónica de Medio Ambiente 2010, 8, 18-40.

9. AGAPA. Caracterización de los Invernaderos de Andalucía; Agencia de Gestión Agraria y Pesquera de Andalucía: Andalucia, Spain, 2015.

10. Muñoz, I.; Gómez, M.M.; Fernandez-Alba, A.R. Life cycle assessment of biomass production in a Mediterranean greenhouse using different water sources: Groundwater, treated wastewater and desalinated seawater. Agric. Syst. 2010, 103, 1-9. [CrossRef] 
11. Gallardo, M.; Thompson, R.B.; Rodriguez, J.S.; Rodriguez, F.; Sanchez, J.A.; Magan, J.J. Simulation of transpiration, drainage, $\mathrm{N}$ uptake, nitrate leaching, and $\mathrm{N}$ uptake concentration in tomato grown in open substrate. Agric. Water Manag. 2012, 96, 1773-1784. [CrossRef]

12. Granados, M.R.; Thompson, R.B.; Fernandez, M.D.; Martinez-Gaitan, C.; Gallardo, M. Prescriptive-corrective nitrogen and irrigation management of fertigated and drip-irrigated vegetable crops using modelling and monitoring approaches. Agric. Water Manag. 2013, 119, 121-134. [CrossRef]

13. CMAOT. Plan Hidrológico 2015. Ciclo de Planificación Hidrológica 2015/2021. Demarcación Hidrográfica de las Cuencas Mediterráneas Andaluzas; Consejería Medio Ambiente y Ordenación del Territorio, Gobierno de España: Madrid, Spain, 2015.

14. Downward, S.R.; Taylor, R. An assessment of Spain's Programa AGUA and its implications for sustainable water management in the province of Almería, southeast Spain. J. Environ. Manag. 2007, 82, 277-289. [CrossRef] [PubMed]

15. IGME. Mapa hidrológico de España; Instituto Geográfico y Minero de España: Madrid, Spain, 1998.

16. Dukes, M.D.; Zotarelli, L.; Morgan, K.T. Use of irrigation technologies for vegetable crops in Florida. HortTechnology 2010, 20, 133-142.

17. Montesano, F.F.; Serio, F.; Mininni, C.; Signore, A.; Parente, A.; Santamaria, P. Tensiometer-based irrigation management of subirrigated soilless tomato: Effects of substrate matric potential control on crop performance. Front. Plant Sci. 2015, 6, 1150. [CrossRef] [PubMed]

18. Yadav, M.R.; Kumar, R.; Ram, H.; Yadav, V.; Yadav, B. Fertigation: An efficient technique for achieving high nutrient use efficiency in crop production system. Marumegh 2017, 2, 2017.

19. Incrocci, L.; Massa, D.; Pardossi, A. New trends in the fertigation management of irrigated vegetable crops. Horticulturae 2017, 3, 37. [CrossRef]

20. Romero, R.; Muriel, J.L.; García, I.; Muñoz de la Peña, D. Research on automatic irrigation control: State of the art and recent results. Agric. Water Manag. 2012, 114, 59-66. [CrossRef]

21. Sunny, C.S.A.C.; Hakkim, V.M.A. Fertigation automation system for poly houses. Int. J. Eng. Sci. Comput. 2016, 6, 3061-3067.

22. Gallardo, M.; Thompson, R.; Rodriguez, J.; Rodriguez, F.; Fernandez, M.; Sanchez, J.; Magan, J. Simulation of transpiration, drainage, $\mathrm{N}$ uptake, nitrate leaching, and $\mathrm{N}$ uptake concentration in tomato grown in open substrate. Agric. Water Manag. 2009, 96, 1773-1784. [CrossRef]

23. García-García, M.C.; Céspedes, A.J.; Lorenzo, P.; Pérez-Parra, J.J.; Escudero, M.C.; Sánchez-Guerrero, M.C.; Medrano, E.; Baeza, E.; López, J.C.; Magán, J.J.; et al. El Sistema de Producción Hortícola de la Provincia de Almería; IFAPA (Instituto de Formación Agraria y Pesquera de Andalucía): Huelva, Spain, 2016; 179p.

24. Morales, I.; Urrestarazu, M. Effect of a passive mixing device on the electrical conductivity and ph values of a nutrient solution. J. Irrig. Drain. Eng. 2014, 140. [CrossRef]

25. Urrestarazu, M.; Morales, I.; La Malfa, T.; Checa, R.; Wamser, A.F.; Alvaro, J.E. Effects of fertigation duration on the pollution, water consumption, and productivity of soilless vegetable cultures. HortScience 2015, 50, 819-825.

26. Rodriguez, D.; Reca, J.; Martinez, J.; Urrestarazu, M. New adaptive hybrid-automatic irrigation control system for soilless culture. J. Irrig. Drain. Eng. 2015, 141, 7. [CrossRef]

27. Céspedes, A.J.; García, M.C.; Pérez-Parra, J.J.; Cuadrado, I.M. Caracterización de la Explotación Hortícola Protegida Almeriense; Fundación para la Investigación Agraria en la Provincia de Almería (FIAPA): Almería, Spain, 2009.

28. Barbieri, G.; Maggio, A. Microirrigation. In Good Agricultural Practices for Greenhouse Vegetable Crops. Principles for Mediterranean Climate Areas; Paper 217; FAO, Plant Production and Protection: Rome, Italy, 2013; pp. 149-168.

29. De Pascale, S.; Barbieri, G.; Rouphael, Y.; Gallardo, M.; Orsini, F.; Pardossi, A. Good Agricultural Practices for Greenhouse Vegetable Production in the South East European countries. In Principles for Sustainable Intensification of Smallholder Farms. 3. Irrigation Management: Challenges and Opportunities; Paper 230; FAO, Plant Production and Protection: Rome, Italy, 2017; pp. 79-105.

30. Fernandez, M.D.; Gonzalez, A.M.; Carreño, J.; Perez, C.; Bonachela, S. Analysis of on-farm irrigation performance in Mediterranean greenhouses. Agric. Water Manag. 2007, 89, 251-260. [CrossRef]

31. Alcon, F.; de Miguel, M.D.; Burton, M. Duration analysis of adoption of drip irrigation technology in southeastern Spain. Technol. Forecast. Soc. Chang. 2011, 78, 991-1000. [CrossRef] 
32. Tarjuelo, J.M.; Rodriguez-Diaz, J.A.; Abadia, R.; Camacho, E.; Rocamora, C.; Moreno, M.A. Efficient water and energy use in irrigation modernization: Lessons from Spanish case studies. Agric. Water Manag. 2015, 162, 67-77. [CrossRef]

33. Sanchez, J.A.; Reca, J.; Martinez, J. Irrigation water management in a Mediterranean greenhouse district: Irrigation adequacy assessment. Irrig. Drain. 2015, 64, 299-313. [CrossRef]

34. Van Iersel, M.W.; Chappell, M.; Lea-Cox, J.D. Sensors for improved efficiency of irrigation in greenhouse and nursery production. HortTechnology 2013, 23, 735-746.

35. Gallardo, M.; Thompson, R.B.; Fernandez, M.D. Good Agricultural Practices for Greenhouse Crop Vegetable Crops: Principles for Mediterranean Climate Areas. 6. Water Requirements and Irrigation Management in Mediterranean Greenhouses: The Case of the Southeast Coast of Spain; Paper 217; FAO, Plant Production and Protection Production: Rome, Italy, 2013; pp. 109-136.

36. Van Iersel, M.W. Modern strategies for irrigation management in protected environments. In Modern Technologies, Strategies and Tools for Sustainable Irrigation Management and Governance in Mediterranean Agriculture (IrriMed 2015); Montesano, F.F., Parente, A., Lamaddalena, N., Todorovic, M., Trotta, L., Eds.; Proceedings-Book of Abstracts; CIHEAM: Valenzano, Italy, 2015; pp. 127-130.

37. Bhatt, R.; Arora, S.; Chew, C.C. Improving irrigation water productivity using tensiometers. J. Soil Water Conserv. 2016, 15, 120-124.

38. Buttaro, D.; Santamaria, P.; Signore, A.; Cantore, V.; Boari, F.; Montesano, F.F.; Parente, A. Irrigation management of greenhouse tomato and cucumber using tensiometer: Effects on yield, quality and water use. Agric. Sci. Procedia 2015, 4, 440-444. [CrossRef]

39. Létourneau, G.; Caron, J.; Anderson, L.; Cormier, J. Matric potential-based irrigation management of field-grown strawberry: Effects on yield and water use efficiency. Agric. Water Manag. 2015, 161, 102-113. [CrossRef]

40. Lao, M.T.; Jiménez, S. Leaching of nutrients in greenhouse cultivation of tomato crop in the Mediterranean area under different fertirrigation managements. J. Food Agric. Environ. 2004, 2, 370-375.

41. Thompson, R.B.; Gallardo, M.; Valdez, L.C.; Fernández, M.D. Using plant water status to define threshold values for irrigation management of vegetable crops using soil moisture sensors. Agric. Water Manag. 2007, 88, 147-158. [CrossRef]

42. Gonzalez, A.M.; Bonachela, S.; Fernandez, M.D. Regulated deficit irrigation in green bean and watermelon greenhouse crops. Sci. Hortic. 2009, 122, 527-531. [CrossRef]

43. Jimenez, S.; Plaza, B.M.; Segura, M.L.; Lao, M.T. Improve water and nutrient efficiency in tomato crop by a dynamic fertigation management under saline conditions. Commun. Soil Sci. Plant Anal. 2012, 43, 258-264. [CrossRef]

44. Contreras, J.I.; Alonso, F.; Cánovas, G.; Baeza, R. Irrigation management of greenhouse zucchini with different soil matric potential level. Agronomic and environmental effects. Agric. Water Manag. 2017, 183, 26-34. [CrossRef]

45. Lao, M.T. Leaching in greenhouses cultivation. In Crops: Growth, Quality and Biotechnology; WFL Publisher Science and Technology: Helsinki, Finland, 2005; pp. 406-431.

46. Plaza, B.M.; Soriano, F.; Jiménez-Becker, S.; Lao, M.T. Nutritional responses of Cordyline fruticosa var. "Red Edge" to fertigation with leachates vs. conventional fertigation: Chloride, nitrogen, phosphorus and sulphate. Agric. Water Manag. 2016, 173, 61-66. [CrossRef]

47. Plaza, B.M.; Paniagua, F.; Ruiz, R.; Jiménez-Becker, S.; Lao, M.T. Nutritional responses of Cordyline fruticosa var. "Red Edge" to fertigation with leachates vs. conventional fertigation: Sodium, potassium, calcium and magnesium. Sci. Hortic. 2017, 215, 157-163. [CrossRef]

48. García-Caparrós, P.; Llanderal, A.; Rodríguez, J.C.; Maksimovic, I.; Urrestarazu, M.; Lao, M.T. Rosemary growth and nutrient balance in response to leachates vs conventional fertigation. Sci. Hortic. 2017, under minor revision.

49. Savvas, D.; Gianquinto, G.; Tuzel, Y.; Gruda, N. Good Agricultural Practices for Greenhouse Vegetable Crops, Principles for Mediterranean Climate Areas. 12. Soilless Culture; Paper 217; FAO, Plant Production and Protection: Rome, Italy, 2013; pp. 303-354.

50. Putra, P.A.; Yuliando, H. Soilless culture system to support water use efficiency and product quality: A review. Agric. Agric. Sci. Procedia 2015, 3, 283-288. [CrossRef] 
51. Grafiadellis, I.; Mattas, K.; Maloupa, E.; Tzouramani, I.; Galanopoulos, K. An economic analysis of soilless culture in Gerbera production. HortScience 2000, 35, 300-303.

52. Raviv, M.; Lieth, J.H. Significance of soilless cultivation in agriculture. In Soilless Culture: Theory and Practice; Academic Press: San Diego, CA, USA, 2008; pp. 1-11.

53. Nejad, A.R.; Ismaili, A. Changes in growth, essential oil yield and composition of geranium (Pelargonium graveolens L.) as affected by growing media. J. Sci. Food Agric. 2014, 94, 905-910. [CrossRef] [PubMed]

54. van Os, E. Closed soilless growing systems: a sustainable solution for Dutch greenhouse horticulture. Water Sci. Technol. 1999, 39, 105-112.

55. Savvas, D. Nutrient solution recycling. In Hydroponic Production of Vegetables and Ornamentals; Embryo Publications: Athens, Greece, 2002; pp. 299-343.

56. Vox, G.; Teitel, M.; Pardossi, A.; Minuto, A.; Tinivella, F.; Schettini, E. Agriculture: technology, planning and management. In Sustainable Greenhouse Systems; Salazar, A., Rios, I., Eds.; Nova Science Publishers: New York, NY, USA, 2010; pp. 1-79.

57. Ahmed, A.K.; Cresswell, G.C.; Haigh, A.M. Comparison of sub-irrigation and overhead irrigation of tomato and lettuce seedlings. J. Hortic. Sci. 2000, 75, 350-354. [CrossRef]

58. Pardossi, A.; Malorgio, F.; Incrocci, L.; Tognoni, F. Hydroponic technologies for greenhouse crops. In Crops: Quality, Growth and Biotechnology; Dris, R., Ed.; WFL Publisher: Helsinki, Finland, 2006; pp. 360-378.

59. Burrage, S.W. Soilless Culture and Water Use Efficiency for Greenhouses in Arid, Hot Climates. 2014. Available online: http:/ / ftp.cgiar.org/icarda/APRP/APRP_2/html/Publications/Right/PrWS/WUE.pdf (accessed on 3 September 2017).

60. Urrestarazu, M.; Mazuela, P.C.; Boukhalfa, A.; Arán, A.; Salas, M.C. Oxygen content and its diurnal variation in a new recirculanting water soilless culture for horticultural crops. HortScience 2005, 40, 1729-1730.

61. Magán, J.J.; Gallardo, M.; Thompson, R.B.; Lorenzo, P. Effects of salinity on fruit yield and quality of tomato grown in soil-less culture in greenhouses in Mediterranean climatic conditions. Agric. Water Manag. 2008, 95, 1041-1055. [CrossRef]

62. Rodríguez, D.; Reca, J.; Martínez, J.; Urrestarazu, M. Automatic irrigation control system for soilless culture based on feedback from drainage hydrograph. Appl. Eng. Agric. 2017, 33, 531-542. [CrossRef]

63. Ayars, J.E.; Basinal, L. A Technical Advisor's Manual. Managing Agricultural Irrigation Drainage Water: A Guide for Developing Integrated On-Farm Drainage Management Systems; Westside Resources Conservation District and Center for Irrigation Technology, California State University: Fresno, CA, USA, 2005.

64. Nichols, M.D.; Davis, G.; Spear, M. San Joaquin Valley Drainage Monitoring Program 1999; District Report of The Resources Agency; Department of Water Resources San Joaquin District: Red Bluff, CA, USA, 2003.

65. Khan, S.; Abbas, A.; Blackwell, J.; Gabriel, H.F.; Ahmad, A. Hydrogeological assessment of serial biological concentration of salts to manage saline drainage. Agric. Water Manag. 2007, 92, 64-72. [CrossRef]

66. Cervinka, V.A. Farming System for the Management of Salt and Selenium on Irrigated Land (Agroforestry); California Department of Food and Agriculture Resources Branch: Sacramento, CA, USA, 1990.

67. Linneman, C.; Falaschi, A.; Oster, J.D.; Kaffka, S.; Benes, S. Drainage reuse by grassland area farmers: The road to zero discharge. In Groundwater Issues and Water Management-Strategies Addressing the Challenges of Sustainability, Proceedings of the USCID Water Management Conference, Sacramento, CA, USA, 4-7 March 2014; Macauley, S., Thoreson, B.P., Anderson, S.S., Eds.; USCID: Bartlett, TN, USA; pp. 65-78.

68. Su, N.; Bethune, M.; Mann, L.; Heuperman, A. Simulating water and salt movement in tile-drained fields irrigated with saline water under a Serial Biological Concentration management scenario. Agric. Water Manag. 2005, 78, 165-180. [CrossRef]

69. Plaza, B.M. Study of the Feasibility of Leachates Reuse for Ornamental Plants Production, within the Framework of a Sustainable Production. Ph.D. Thesis, University of Almería, Almería, Spain, 2013.

70. García-Caparrós, P.; Llanderal, A.; El-Tarawy, A.; Maksimovic, I.; Lao, M.T. Crop and irrigation management systems under greenhouse conditions. Water 2017, under review.

71. Huang, C.; Zeng, P.; Yang, S.; Shao, Y.; Liu, Y. Water reclamation and reuse. Water Environ. Res. 2016, 88, 1261-1278. [CrossRef] [PubMed]

72. Bhardwaj, N. Integrated system of phytodepuration for agro-industrial waste water-An ecofriendly technology. Recent Res. Sci. Technol. 2013, 5, 100-102. 
73. Andreo-Martínez, P.; García-Martínez, N.; Quesada-Medina, J.; Almela, L. Domestic wastewaters reuse reclaimed by an improved horizontal subsurface-flow constructed wetland: A case study in the southeast of Spain. Bioresour. Technol. 2017, 233, 236-246. [CrossRef] [PubMed]

74. Vymazal, J. Constructed wetlands for wastewater treatment. Water 2010, 2, 530-549. [CrossRef]

75. Fonder, N.; Headley, T. Systematic classification, nomenclature and reporting for constructed treatment wetlands. In Water and Nutrient Management in Natural and Constructed Wetlands; Vymazal, J., Ed.; Springer: Dordrecht, The Netherlands, 2010; pp. 191-219.

76. Vymazal, J. Emergent plants used in free water surface constructed wetlands: A review. Ecol. Eng. 2013, 61, 582-592. [CrossRef]

77. Abou-Elela, S.I.; Hellal, M.S. Municipal wastewater treatment using vertical flow constructed wetlands planted with Canna, Phragmites and Cyprus. Ecol. Eng. 2012, 47, 209-213. [CrossRef]

78. Zhang, D.Q.; Jinadasa, K.B.S.N.; Gersberg, R.M.; Liu, Y.; Jern, W.; Keat-Tan, S. Application of constructed wetlands for wastewater treatment in developing countries: A review of recent developments (2000-2013). J. Environ. Manag. 2014, 141, 116-131. [CrossRef] [PubMed]

79. Malaviya, P.; Singh, A. Constructed wetlands for management of urban stormwater runoff. Crit. Rev. Environ. Sci. Technol. 2012, 42, 2153-2214. [CrossRef]

80. Avila, C.; Salas, J.J.; Martin, I.; Aragon, C.; García, J. Integrated treatment of combined sewer wastewater and stormwater in a hybrid constructed wetland system in southern Spain and its further reuse. Ecol. Eng. 2013, 50, 13-20. [CrossRef]

81. Ballantine, D.J.; Tanner, C.H. Substrate and filter materials to enhance phosphorus removal in constructed wetlands treating diffuse farm runoff: A review. N. Z. J. Agric. Res. 2010, 53, 71-95. [CrossRef]

82. Diaz, F.; O'Geen, A.T.; Dahlgren, R.A. Agricultural pollutant removal by constructed wetlands: Implications for water management and design. Agric. Water Manag. 2012, 104, 171-183. [CrossRef]

83. Dordio, A.; Carvalho, A.J.P. Constructed wetlands with light expanded clay aggregates for agricultural wastewater treatment. Sci. Total Environ. 2013, 463, 454-461. [CrossRef] [PubMed]

84. Vymazal, J.; Brezinová, T. The use of constructed wetlands for removal of pesticides from agricultural runoff and drainage: A review. Environ. Int. 2015, 75, 11-20. [CrossRef] [PubMed]

85. Tournebize, J.; Chaumont, C.; Mander, U. Implications for constructed wetlands to mitigate nitrate and pesticide pollution in agricultural drained watersheds. Ecol. Eng. 2017, 103, 415-425. [CrossRef]

86. García-Caparrós, P.; Llanderal, A.; El-Tarawy, A.; Correia, P.J.; Pestana, M.; Lao, M.T. Irrigation with drainage solutions improves the growth and nutrients uptake in Juncus acutus. Ecol. Eng. 2016, 95, 237-244. [CrossRef]

87. Morillo, J.; Usero, J.; Rosado, D.; El Bakouri, H.; Riaza, A.; Bernaola, F.J. Comparative study of brine management technologies for desalination plants. Desalination 2014, 336, 32-49. [CrossRef]

88. Wada, Y.; Bierkens, M.F. Sustainability of global water use: past reconstruction and future projections. Environ. Res. Lett. 2014, 9, 104003. [CrossRef]

89. Greenlee, L.F.; Lawler, D.F.; Freeman, B.D.; Marrot, B.; Moulin, P. Reverse osmosis desalination: Water sources, technology, and today's challenges. Water Res. 2009, 43, 2317-2348. [CrossRef] [PubMed]

90. David, B.; Pinot, J.P.; Morrillon, M. Beach wells for large-scale reserve osmosis reverse: The Sur case study. In IDA World Congress-Atlantis; The Palm: Dubai, UAE, 2009.

91. Sola, F.; Vallejos, A.; López-Geta, J.A.; Pulido-Bosch, A. The role of aquifer media in improving the quality of seawater feed to desalination plants. Water Resour. Manag. 2013, 27, 1377-1392. [CrossRef]

92. Peters, T.; Pintó, D. Seawater intake and pre-treatment/brine discharge: environmental issue. Desalination 2008, 221, 576-584. [CrossRef]

93. Anderson, D.J.; Timms, W.A.; Glamore, W.C. Optimising subsurface well design for coastal desalination water harvesting. Aust. J. Earth Sci. 2009, 56, 53-60. [CrossRef]

94. Pulido-Bosch, A.; Vallejos, A.; Sola, F. Reflexiones Sobre las Plantas Desaladoras de Andalucía; Instituto Geológico y Minero de España: Madrid, Spain, 2015.

95. Roberts, D.A.; Johnston, E.L.; Knott, N.A. Impacts of desalination plant discharges on the marine environment: a critical review of published studies. Water Res. 2010, 44, 5117-5128. [CrossRef] [PubMed]

96. Siddiqi, A.; Diaz-Anadon, L. The water-energy nexus in Middle East and North Africa. Energy Policy 2011, 39, 4529-4540. [CrossRef] 
97. Domènech, L.; March, H.; Saurí, D. Degrowth initiatives in the urban water sector? A social multi-criteria evaluation of non-conventional water alternatives in Metropolitan Barcelona. J. Clean. Prod. 2013, 38, 44-55. [CrossRef]

98. Zarzo, D.; Campos, E.; Terrero, P. Spanish experience in desalination for agriculture. Desalin. Water Treat. 2013, 51, 53-66. [CrossRef]

99. Valera, D.L.; Marín, P.; Camacho, F.; Belmonte, L.J.; Molina, F.; López, A. Captación de Datos de Campo y Análisis Para la Toma de Decisiones Sobre el Consumo de Agua, Desalada y de Pozos Para los Cultivos de Tomate, Sandía y Pimiento; I Jornadas de Transferencia Hortofruticola de CIAMBITAL: Almería, Spain, 2017; pp. 103-138.

100. Aznar-Sánchez, J.A.; Belmonte-Ureña, L.J.; Valera, D.L. Perceptions and acceptance of desalinated seawater for irrigation: A case study in the Nijar district (Southeast Spain). Water 2017, 9, 408. [CrossRef]

101. Papadopoulos, I.; Savvides, S. Optimisation of the use of nitrogen in the treated wastewater reused for irrigation. Water Sci. Technol. Water Supply 2003, 3, 217-221.

102. Rodriguez-Manzano, J.; Alonso, J.L.; Ferrús, M.A.; Moreno, Y.; Amorós, I.; Calgua, B.; Hudesa, A.; Guerrero-Latorre, L.; Carratala, A.; Rusiñol, M.; et al. Standard and new faecal indicators and pathogens in sewage treatment plants, microbiological parameters for improving the control of reclaimed water. Water Sci. Technol. 2012, 66, 2517-2523. [CrossRef] [PubMed]

103. Chen, Y.; Wang, C.; Wang, Z.; Huang, S. Assessment of the contamination and genotoxicity of soil irrigated with wastewater. Plant Soil 2004, 261, 189-196. [CrossRef]

104. Alonso, C. Reutilización de aguas residuales urbanas, su aplicación al regadío: Ozonificación. Riegos y Drenajes XXI 1993, 70, 18-24.

105. Norton-Brandão, D.; Scherrenberg, S.M.; van Lier, J.B. Reclamation of used urban waters for irrigation purposes-A review of treatment technologies. J. Environ. Manag. 2013, 122, 85-98. [CrossRef] [PubMed]

106. García-Delgado, C.; Eymar, E.; Contreras, J.; Segura, M.L. Effect of disinfection systems on the content of inorganic and organic contaminants in urban wastewater. Acta Hortic. 2010, 852, 269-274. [CrossRef]

107. Martínez, S.B.; Peréz-Parra, J.; Suay, R. Use of ozone in wastewater treatment to produce water suitable for irrigation. Water Resour. Manag. 2011, 25, 2109-2124. [CrossRef]

108. Segura, M.L.; Contreras, J.; García-Delgado, C.; Eymar, E. Use of disinfected wastewater for pepper fertigation in Almería (Spain): Evaluation of chemical risks in soil and leachates. Acta Hortic. 2010, 852, 275-282. [CrossRef]

109. Martínez, S.; Suay, R.; Moreno, J.; Segura, M.L. Reuse of tertiary municipal wastewater effluent for irrigation of Cucumis melo L. Irrig. Sci. 2013, 31, 661-672. [CrossRef]

110. Segura, M.L.; Contreras, J.I.; Plaza, B.M.; Lao, M.T. Assessment of the nitrogen and potassium fertilizer in green bean irrigated with disinfected urban wastewater. Commun. Soil Sci. Plant Anal. 2012, 43, 426-433. [CrossRef]

111. De Miguel, J.; López, J.G.; Baeza, R. Use of desalinated water in agriculture. Experiences in Almería (Spain). In Proceedings of the IDA World Congress, Perth, Australia, 4-9 September 2011. IDAWC/pr11-129.

112. Baeza, R.; Contreras, J.I.; Parra, M.M.; López, J.G.; López, F.; Lao, M.T.; Sierra, A.J. Caracterización y Mezclas de los Diferentes Recursos Hídricos Para la Sostenibilidad del Riego de Cultivos Hortícolas Intensivos en el Campo de Dalias. 2017. Available online: http:/ / www.agronomoscentro.org/index.php/a-investigaciondesarrollo-e (accessed on 3 September 2017).

113. Del Villar, A. El Coste Energético de la Desalinización en el Programa A.G.U.A. Investigaciones Geográficas. 2014. Available online: http:/ / www.redalyc.org/articulo.oa?id=17632456007 (accessed on 3 September 2017).

114. Melgarejo, J.; López, M.I. Depuración y reutilización de aguas en España. Agua y Territorio 2016, 8, $22-35$. [CrossRef]

(C) 2017 by the authors. Licensee MDPI, Basel, Switzerland. This article is an open access article distributed under the terms and conditions of the Creative Commons Attribution (CC BY) license (http:/ / creativecommons.org/licenses/by/4.0/). 